\title{
Assess the lean performances in Vietnamese companies - a multi-case study in manufacturing firms
}

- Bui Nguyen Hung

- Le Phuoc Luong

- Nguyen Thi Hong Dang

University of Technology, VNU-HCM

(Manuscript Received on July 31 $1^{\text {st }}$,2013, Manuscript Revised October 04 ${ }^{\text {th }}$, 2013)

\begin{abstract}
:
This study is conducted to assess the Lean performances of 10 Vietnamese manufacturing companies in terms of 13 factors proposed by Hirano (2009). Managers of 6 large companies and 4 small and medium ones are invited to participate in semi-structured interviews to assess their own company's Lean performances and raise the ideas for their assessments. The research results show that large companies perform better than the small and medium ones in all 13 factors. As a whole, the studied companies

operations in terms of awareness revolution, the 5S's, multi-process operations, labor cost reduction, visual control, quality assurance, standard operations, maintenance and safety. These companies have to effort much more in flow production, Kanban, leveled production, change-over, and human automation. To survive in the context of today Vietnam economy, these companies should focus on long-term strategies to take advantages of Lean philosophy for their future development.
\end{abstract} apply Lean at acceptable levels for their

Keywords: Lean performance, manufacturing company, Vietnam. \section{INTRODUCTION}

Lean systems are implemented to achieve longterm strategic gains as the case of Toyota in the automotive industry (Smart et al., 2003). Other examples, including such iconic names as: Boeing, Daimler AG and Hershey, apply Lean to attain high performance as Toyota (Sonntag et al., 2009). However, the existing paradox is that Lean has been used in most companies not for its advantage to attain strategic competitiveness, but to gain short-term cost reductions. The Lean utilization of many organizations is often unplanned rather than a systems approach (Chong et al., 2001). This misuse of Lean has caused the decrease in the overall organizational performance (Naslund, 2008) and made companies a thought of seeking short-term

efficiency (Smart et al., 2003). This kind of Lean approach has raised questions about sustainability within enterprises applying Lean to reduce costs while losing sight of their mission and integrity (Smart et al., 2003).

Ransom (2007), chairman of American Lean Horizons Consulting LLC., mentions that $95 \%$ of the Lean implementation efforts have failed, while only $5 \%$ have been successful. Wooley (2008), a strategic program manager of Intel Corp, states that about $60 \%$ of Lean transformation efforts fail. According to the Lean Enterprise Institute (2008), these high rates of failure are the results of following top five factors: (1) Backsliding, (2) Middle management resistance, (3) Lack of implementation know- 
how, (4) Lack of crisis, (5) Employee resistance. In Vietnam, Lean has been applied to more and more companies and it is not still a really new concept. However, as to an expert of Vietnam Lean Symposium, the first International Conference of Lean implementation in all industries of Vietnam, around $75 \%$ Vietnamese companies know and apply Lean for their operations; yet, only $2 \%$ of these companies achieve the successes (FBNC Vietnam, 2013).

The causes of Vietnamese companies' failures in applying Lean are not mentioned officially in previous studies. Nguyen and Bui (2010) suggest that Vietnamese companies should focus on creating a strong corporate Lean culture to be successful, in which they believe that the commitments of top managers and the participation of all employees are two factors making the success of Lean implementation for Vietnamese organizations. However, there is a lack of study which assesses the Lean adoption as well as Lean performance of Vietnamese companies. It is believed that Vietnamese companies really need practical advices for Lean adoption (Nguyen \& Bui, 2010) through realistic experiences. Thus, this study is conducted with the cases of manufacturing companies in Vietnam to assess their Lean performances in multi criteria that cover all aspects of Lean philosophy such as: awareness revolution, the $5 \mathrm{~S}$ 's, flow production, multi-process operations, labor cost reduction, Kanban, visual control, level production, changeover, quality assurance, standard operations, human automation, maintenance and safety (Hirano, 2009).

Besides, Elbert (2013) and Harrison (1994) believe that Lean manufacturing is more suitable for small and medium than the large ones while Janet and Will (2007) insist that greater business scale and business scope enhance long-term survival and profitability. For this reason, the study also focuses on the differences in Lean performances between the two groups of Vietnamese manufacturing companies: the large ones and the SME (small and medium enterprises) to have a comparative conclusion of their abilities in Lean implementation. The research results draw a picture of Lean adoption levels at these manufacturing firms and give useful advices for companies in Lean implementation to gain their competitive advantages in the context of today Vietnam economy.

\section{LITERATURE REVIEW}

\section{Lean production and Lean culture}

Lean manufacturing is applied in firms to identify wasteful practices, reduce costs, and increase quality. Lean is concluded to benefit companies with shorter cycle time, shorter lead times, lower WIP, faster response time, lower cost, greater production flexibility, higher quality, better customer service, higher revenue, higher throughput; and increased profit (Womak \& Jones, 2005). It is believed that Lean is neither a method nor a tool, but it is a philosophy; thus, the success of Lean implementation is strictly related to corporate culture. Bhasin (2013) reveals that a triumphant implementation of Lean requires a systematic and controlled strategy to look at the prevailing culture. Lean failures are attributable to different causes in which the fundamental issues of corporate culture and change are ones of the most important issues. It is proposed that a Lean culture can be defined as assimilating the following elements: ensuring decisions are made at the lowest level (Corbett, 2011); a shared vision amongst all employees to be evident (Wan \& Chen, 2008); evidence of a participative leadership style with greater collaboration (Atkinson, 2010); the culture promoting the existence of a continuous pursuit for perfection (Hines et al., 2008); teamwork through total involvement and committed personnel (Eisenhardt \& Martin, 2010); appropriate communications about the overall goals and performance (Shook, 2010); the work provides personal and professional satisfaction for the employees (Ransom, 2008); collaboration between the highly skilled workers and management (Singh et al., 2010); the total workforce sharing the gains (Vinodh \& Balaji, 2011); and existence of few or no boundaries between functions (Shook, 2010).

\section{Relevant studies of Lean performance}

Quantifying the benefits of Lean is not an easy task (Womack \& Jones, 2005). Lean philosophy focuses on total system efficiency (Standard \&

\section{Trang 26}


Davis, 2000). Therefore, the best criterion to assess a lean progress is total product cycle time since long cycle times also cause high-production costs; in the converse, short cycle times also result lower production costs. However, no single performance criterion can cover the organizational complexity. It is understandable to state that measuring lean performance of an organization is a real challenge for both managers and researchers (Bhasin, 2008).

Many companies use the balanced scorecard as a measurement for their lean performances (Kaplan \& Norton, 2005). However, the the balanced scorecard has recently considered as inadequate in some circumstances (Bhasin, 2008). Therefore, the dynamic multi-dimensional performance (DMP) framework proposed by Maltz et al. (2003) is used as an appropriate framework for lean performance. DMP is a dynamic and multi-dimensional framework which captures many aspects of an organization and represents multiple stakeholders. DMP is consisted of 12 potential "baseline measures" which are attributed to 5 dimensions: financial, market, process, people, and future. Yet, Bhasin (2008) states that not all the measures proposed in DMP framework may be appropriate at any time. Instead, each company should learn how to use the components of the framework in different ways with different levels of importance. The suitable package of measures should be chosen based on the firm's size, technology, strategy, together with the natures of the relevant industry and environment in which the firm runs. This means that DMP is not a good choice for all companies to measure their lean performances, but they are required to base on the experiences and abilities of the top managers to determine which measures are appropriate for their companies.

In manufacturing companies, the lean performance is measured through VSM (Value stream mapping) by some researchers (Wan et al., 2007; Wu \& Wee, 2009). Wan et al. (2007) use VSM to measure the overall lean performance in which cost, time and output values are considered but the effectiveness of production compared to company objective is not concluded; whereas, Wu and Wee (2009) gauge only the overall effectiveness of using equipment, but they ignore evaluating the efficiency as well as overall performance. Wan and Chen (2008) also appreciates the role of VSM when addressing this one together with lean assessment tools and lean metrics as the three pillars of lean measurement. Agus and Hajinoor (2012) believe that the adoption of lean tools place a very important role in improving the lean performance. These authors utilize structural equation modeling (SEM) to recognize the relationship between lean tools and lean performance in production companies.

\section{Measurement of Lean performance in this study}

One of the limitations of above measurements of Lean performance is that they do not cover all aspects of Lean adoption in manufacturing companies. Moreover, in comparison of qualitative surveys, quantitative metrics provide a better lean score (Karim \& Zaman, 2013). Thus, in this study, the Lean measurements of Hirano (2009) are used with 13 factors. They are: awareness revolution, the 5S's, flow production, multi-process operations, labor cost reduction, kanban, visual control, level production, changeover, quality assurance, standard operations, human automation, maintenance and safety. Awareness revolution measures the level of customer orientation of employees in the whole factory. The $5 \mathrm{~S}$ assesses the level of $5 \mathrm{~S}$ implementation in the firm. Flow production is the factor that helps the managers to know how far the firm is from the one-piece flow production. Multi-process operations measure the ability of operators in handling all processes in their working cells. Labor cost reduction assesses the lean level in utilizing labor in terms of both quantity and quality. Kanban is the criterion that evaluates the useful level of Kanban in the production systems. Visial control measures the ability of employees to recognize and respond to abnormalities. Leveled production focuses on the establishment of fullyleveled schedule for the production in the firm and the level of the cycle time to set the rhythm for entire the factory. Change-over presents the ability of change-over teams in improving change-over cycle time. Quality assurance assesses the ability of the firm in using Lean 
tools to build quality standard in each process and detect defects at their source to prevent occurrence. Standard operations measure the ability of the firm to define standard operations well, and follow as well as improve these operations. Human automation assesses the separation between workers and machines and the ability of employees to stop the machines which release defective goods. Finally, maintenance and safety measure the ability of the firm in company-wide maintenance as well as focus on the machine breakdowns and accidents occurred in the company.

These 13 factors are considered to cover all the principles of Lean implementation in a production firm. These factors are quantified through 5 levels of lean adoption: little league (level 1), junior varsity (level 2), varsity (level 3), minor league pro (level 4), and major league pro (level 5). The Hirano's measures and levels are shown in the figure 1 .

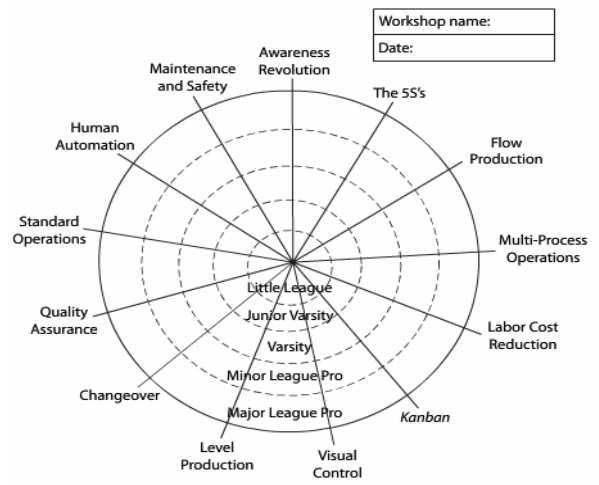

Figure 1: Lean Production Radar Chart (Source: Hirano, 2009)

As shown in the figure 1, a manufacturing company can be classified into 5 levels of Lean performance in accordance with 13 mentioned factors. This company can get high scores for some factors and low scores for the others. The results of its performance depend on the company's efforts for each factor. In general, Hirano (2009) distinguishes these 5 levels as the following:

Little league: This level is typical of struggling, money-losing company whose survival is in doubt

Junior varsity: Companies at this level are managing to survive, for the time being at least
Varsity: Companies at this level are doing just well enough to not be ashamed to host factory tours.

Minor league pro: At this level, companies are doing well enough to take pride in being able to teach other companies a thing or two.

Major league pro: These top-ranking companies truly have what it takes to survive into the $21^{\text {st }}$ century.

\section{RESEARCH METHODOLOGY}

In this study the enterprises are chosen based on the convenient sampling with 6 large companies and 4 small and medium ones to assess and compare the Lean performances of these two kinds of companies. According to Vietnamese Government (2009), enterprises which have the average labor amount of less than 300 are considered as small and medium ones while enterprises which have more than 300 employees are classified as large ones. These companies, both large and SME companies, run their businesses in different industries such as daily products, cigarette, petroleum, electricity, mechanics, and plastic. These ten companies have already applied Lean for over than 1 year and used multiple Lean tools such as 5S, Kanban, Jidoka, Poka-yoke, leveled production, visual controls, and so on for their operations. Large companies in Vietnam have more sufficient resources such as finance and human to approach the Lean philosophy and apply it for their production sooner than the small and medium ones. Thus, it is believed that the number of large Vietnamese companies applying Lean is greater than the small and medium ones. For this reason, in this study, the quantity of large ones chosen is 6 being greater than the number of small and medium ones with 4.Ten managers including production managers, lines managers, and general managers of the ten companies are chosen as respondents for this study. The managers chosen in this study are ones who directly manage or control the Lean action plans so that they have sufficient experiences and abilities to assess the Lean performances of the firms. The information about these managers is presented in the Table 1.

\section{Trang 28}


Table 1: Information of chosen managers for the study

\begin{tabular}{|c|c|c|c|c|}
\hline $\begin{array}{l}\text { Manager } \\
\text { name }\end{array}$ & Company & Job title & Lean experience & Used Lean tools \\
\hline Mr. K & A & Production manager & 2 years & 5S, Kanban, Poka-yoke \\
\hline Mr. T & $\mathrm{B}$ & $\begin{array}{c}\text { Manufacturing } \\
\text { director }\end{array}$ & 1.5 years & $\begin{array}{c}\text { 5S, Multi-task worker, Poka-yoke, Operational } \\
\text { Standardization }\end{array}$ \\
\hline Mr. S & $\mathrm{C}$ & Lines manager & 3 years & 5S, Kaizen, Jidoka, Operational Standardization \\
\hline Ms. H & $\mathrm{D}$ & Factor manager & 4 years & $\begin{array}{l}\text { 5S, Multi-task worker, Kanban, Visual control, } \\
\text { Kaizen, VSM, Operational Standardization }\end{array}$ \\
\hline Mr. B & $\mathrm{E}$ & Factor manager & 4 years & $\begin{array}{c}\text { 5S, Visual control, Poka-yoke, VSM, Operational } \\
\text { Standardization }\end{array}$ \\
\hline Mr. M & $\mathrm{F}$ & Production manager & 3 years & $\begin{array}{l}\text { Leveled production (Heijunka), Preventive } \\
\text { maintenance, Jidoka }\end{array}$ \\
\hline Mr. D & $\mathrm{G}$ & Manager & 3.5 years & Kanban, Kaizen \\
\hline Mr. N & $\mathrm{H}$ & Manager & 2 years & Multi-task worker, Kaizen \\
\hline Ms. T & $\mathrm{I}$ & Owner & 2 years & Operational Standardization, Preventive Maintenance \\
\hline Mr. P & $\mathrm{J}$ & Production manager & 2 years & Visual control, Operational Standardization \\
\hline
\end{tabular}

These managers are asked to assess their corporate lean performances through scoring 13 factors proposed by Hirano (2009). Each factor is scored from 1 to 5 . Level 1 presents the lowest score and level 5 are the highest score that each factor is marked. Then, the managers are invited for semi-structured interviews. Based on the scores marked by each manager, this person is interviewed deeply about the scores. In some cases, the scores do not match the explanations of the managers so that the managers are asked to correct the scores. These managers are also asked for their ideas about the problems that they meet during the time of Lean implementation as well as the solutions they would like to apply in the future.

Together with the qualitative data, quantitative data are used to analyze and assess the Lean performances of all enterprises. The mean scores of each factor for six large companies are used to compare with the mean scores of this factor for four small and medium companies to explore the differences between the two groups of companies. The overall average scores of each factor are calculated by the mean of all scores of this factor for all ten companies. These overall average scores are used to draw an overall picture (Lean radar chart) for all studied companies. Based on this picture, strengths and weaknesses of Lean implementation in these ten companies are revealed. The solutions to improve Lean performances are given based on this picture and the ideas of managers taken from the semistructured interviews.

\section{RESEARCH RESULTS}

\section{Overall status of the ten companies}

The Lean performances of 10 manufacturing firms in Vietnam are shown in the table 2. As in the table, the companies are clasified into two groups in accordance with their sizes. Six companies with their large sizes include A, B, C, $\mathrm{D}, \mathrm{E}, \mathrm{F}$ while four other companies (including $\mathrm{G}$, $\mathrm{H}, \mathrm{I}, \mathrm{J})$ have small and medium sizes. As a whole, large companies have better Lean performances than small and medium ones in all aspects of Lean implementation. In more details, large companies have acceptable results (mean scores are higher than 3.0) of Lean application for 10 criteria: awareness revolution, the 5S's, flow production, multi-process operations, labor cost reduction, kanban, visual control, quality assurance, standard operations, maintenance and safety. Meanwhile, small and medium firms only attain acceptable performances in 3 criteria: awareness revolution, standard operations, maintenance and safety. The overall average scores of all companies are shown in the table 2 as well as pictured in the figure 2 . In total, the manufacturing companies in this study apply Lean quite well for their operations in terms of awareness revolution, the 5S's, multi-process operations, labor cost reduction, visual control, quality assurance, standard operations, maintenance and safety.

Lean performances in accordance with each criterion for the two groups of companies 
In terms of Awareness revolution, in general, both groups of the companies have good practices of customer-orientation. The scores for both groups are 3.5; this means that the companies are classified into the range between level 3 (Varsity) and level 4 (Minor league pro). In this range, the companies know how important the customer orientation is and the firms are gradually beginning to reflect this. However, in the group of large firms, company A just reaches the level 1 (little league) of awareness revolution. $\mathrm{Mr}$. K, the production manager of company A, says that the goals of the department focus on large-lot production to assure the service level, the other terms of customer orientation are something outside the factory. Most of employers in the factory prefer the current ways of making products instead of thinking of improvements for their daily jobs.

About the 5S implementation, large companies have much better performances than small companies with the scores 4.0 (level 4: minor league pro) and 1.8 (between level 1: little league and level 2: junior varsity) respectively. All large companies recognize the importance of $5 \mathrm{~S}$ for Lean adoption. Ms. $\mathrm{H}$, factory manager of company D, kindly shares that "We know $5 \mathrm{~S}$ is extremely necessary for Lean, and all employees in the factory are eager for $5 \mathrm{~S}$ adoption and maintenance". Yet, Mr. D, the general manager of company G, states that "We know about 5S, but it is not now for $5 \mathrm{~S}$ ". This result shows that larger companies in Vietnam seem to care much more about working environment than smaller ones.

Table 2: Lean performances of Vietnamese companies with 13 criteria proposed by Hirano (2009)

\begin{tabular}{|c|c|c|c|c|c|c|c|c|c|c|c|c|c|c|}
\hline Company size & Name & $\begin{array}{l}\text { Awareness } \\
\text { Revolution }\end{array}$ & The 5S's & $\begin{array}{c}\text { Flow } \\
\text { production }\end{array}$ & \begin{tabular}{|c|} 
Multi- \\
Process \\
Operations \\
\end{tabular} & $\begin{array}{c}\text { Labor Cost } \\
\text { Redution }\end{array}$ & Kanban & $\begin{array}{c}\text { Visual } \\
\text { Control }\end{array}$ & $\begin{array}{c}\text { Level } \\
\text { Production }\end{array}$ & Changeover & $\begin{array}{c}\text { Quality } \\
\text { Assurance }\end{array}$ & $\begin{array}{c}\text { Standard } \\
\text { Operations }\end{array}$ & $\begin{array}{c}\text { Human } \\
\text { Automation }\end{array}$ & $\begin{array}{c}\text { Maintenance } \\
\text { and Safety }\end{array}$ \\
\hline Large & $\mathrm{A}$ & 1 & 4 & 5 & 3 & 5 & 4 & 3 & 1 & 1 & 5 & 3 & 2 & 3 \\
\hline Large & B & 3 & 4 & 2 & 4 & 4 & 3 & 3 & 3 & 2 & 5 & 5 & 2 & 4 \\
\hline Large & $\mathrm{C}$ & 4 & 4 & 2 & 3 & 5 & 3 & 3 & 1 & 1 & 4 & 4 & 4 & 5 \\
\hline Large & $\mathrm{D}$ & 4 & 5 & 2 & 3 & 5 & 3 & 5 & 3 & 3 & 5 & 5 & 3 & 4 \\
\hline Large & $\mathrm{E}$ & 5 & 4 & 3 & 5 & 5 & 3 & 5 & 3 & 5 & 4 & 5 & 2 & 3 \\
\hline Large & $\mathrm{F}$ & 4 & 3 & 5 & 3 & 2 & 3 & 2 & 4 & 4 & 1 & 4 & 4 & 4 \\
\hline \multicolumn{2}{|l|}{ Mean } & 3.5 & 4.0 & 3.2 & 3.5 & 4.3 & 3.2 & 3.5 & 2.5 & 2.7 & 4.0 & 4.3 & 2.8 & 3.8 \\
\hline Small \& Medium & G & 5 & 1 & 1 & 4 & 5 & 3 & 2 & 1 & 2 & 2 & 3 & 1 & 4 \\
\hline Small \& Medium & $\mathrm{H}$ & 2 & 2 & 2 & 3 & 1 & 2 & 2 & 2 & 2 & 2 & 2 & 2 & 2 \\
\hline Small \& Medium & I & 4 & 2 & 2 & 2 & 3 & 2 & 3 & 3 & 2 & 1 & 4 & 2 & 4 \\
\hline Small \& Medium & $\mathrm{J}$ & 3 & 2 & 1 & 1 & 2 & 2 & 3 & 2 & 2 & 2 & 3 & 2 & 3 \\
\hline Mean & & 3.5 & 1.8 & 1.5 & 2.5 & 2.8 & 2.3 & 2.5 & 2.0 & 2.0 & 1.8 & 3.0 & 1.8 & 3.3 \\
\hline Overall average & & 3.5 & 3.1 & 2.5 & 3.1 & 3.7 & 2.8 & 3.1 & 2.3 & 2.4 & 3.1 & 3.8 & 2.4 & 3.6 \\
\hline
\end{tabular}

Large companies also attain very good performances in Lean application in terms of: Labor cost reduction (4.3), Quality assurance (4.0), and Standard operations (4.3). These large companies achieve the level 4 (minor league pro) for the three factors. This means that these large companies utilize Lean to reduce the labor cost of the processes in which job duties are adaptable to changes in required outputs. Besides, these companies reach the status that defects are detected before being passed to the next process by operators who perform independent inspections and improvements. Moreover, these large companies also benefit from Lean for the fact that systematic production standards are followed at each process. Mr. T, the manufacturing director of company $\mathrm{B}$, claims that Lean philosophy is practically useful for the firm to reduce the costs related to labor and production. The company already employed Jidoka and poka-yoke to build quality standards at each process and prevent the occurrence of potential defects. Mr. B., the factory manager of company E, states that "our company is quite big; thus, we would like to focus on the continuous improvement of operations for sustainable development, and Lean theories help us a lot in operational standardization and improvement". Among the large enterprises, company $\mathrm{F}$ is not successful in Lean implementation for labor cost reduction as well as quality assurance. The same results as company $\mathrm{F}$ are the cases of the small

\section{Trang 30}


and medium companies when they just get the scores for labor cost reduction and quality assurance as 2.8 (between level 2: junior varsity and level 3: varsity) and 1.8 (between level 1: little league and level 2: junior league) respectively. That means, in these companies, the balance between job duties and number of employees is basically poor and lots of defective products are delivered and cause a lot of customer complaints. Mr. $\mathrm{P}$, the production manager of company J, blames that "We applied Lean two years ago. We know that we need to make our staff lean for both quality and quantity, but now we still do not have a good policy for labor utilization. Overstaffing occurs usually".

In terms of Flow production, Multi-process operations, Kanban, and Visual control, the large companies get the acceptable scores for the four factors with 3.2, 3.5, 3.2, and 3.5 respectively. These companies are categorized in the range between level 3 (Varsity) and level 4 (Minor league pro) for these factors. These large firms have arranged the equipment for in-line layout, but production flow is limited to the single-process and small-lot method. The companies also use Kanban and other Visual control to manage the number of Work-InProcess items as well as control the abnormalities in manufacturing processes. However, the implementation of these tools is just in an acceptable level. Mr. S, the lines manager of company $\mathrm{C}$, responds that "We know about onepiece flow, Kanban as well as Visual control in Lean. Yet, we cannot reach the one-piece flow now; it is far away for our company to attain this criterion. We are applying Kanban and other visual control such as different uniforms for different kinds of employees, dangerous caution, and so on. We are on the way to switch push production to pull production". For these four factors, small and medium companies have even lower scores than large ones with flow production (1.5), multi-process operations (2.5), Kanban (2.3), and Visual control (2.5). With these cores, these companies can be classified into the level 2 (junior varsity) for these factors. This means that the equipment layout in these firms is still in the job-shop style, and the production relies heavily on the conveyance system. The employees in these companies may not know how to do the jobs of other processes. Besides, push production still prevails in these companies, but things are generally organized into specified temporary storage areas. Visual control is not well deployed in these companies since no one can tell when an abnormality occurs, although, they are eventually discovered and corrected. Mr. $\mathrm{P}$, the production manager of company J, also blames that "I do not think that the idea of one-piece flow is practically feasible in our company. Besides, we encourage the employees to specialize their jobs so that multiprocess operations are not necessary here. We already employed some visual controls but there are many things to do with a Kanban system. Similarly, we know we also have many things to do with Lean".

Both kinds of companies have low scores for the three factors: Leveled production, Changeover, and Human automation. The scores of these three factors for the large companies are 2.5, 2.7, and 2.8 respectively while these cores for the small and medium firms are 2.3, 2.4, and 2.4. With these cores, the companies belong to the range between level 2 (junior varsity) and level 3 (varsity) for these three factors. This shows that in the companies, each product model has only some runs per month, and each process moves at its own pitch. Besides, people in the companies are conscious of the need to orient change-overs toward serving customer needs. However, they do not have a plan for change-over improvement as well as reduce the change-over time. In these companies, it is seen that operations are done by machines but always with human assistance. Mr. N, the manager of company $\mathrm{H}$, answers that the firm does not have a good schedule of leveled production and it needs more efforts for leveled production to reduce wastes related to non-added value time. The company also takes some change-overs to meet the customer requirements; yet, no one in the firm thinks of ways for changeover improvements. Mr. $\mathrm{N}$ also states that the company really needs more automation of machines and delivers more rights for the workers to stop the machines at any time when defective products are seen. 
Finally, in terms of maintenance and safety, both kinds of companies have acceptable scores with 3.8 for large companies and 3.6 for small and medium ones. With these cores, the companies belong to the range between level 3 (varsity) and level 4 (minor league pro) for this factor. The result shows that, in the companies, thorough maintenance and repairs are done after breakdowns occur, and major accidents rarely occur. Besides, the companies also deploy the preventive maintenance; yet, the firms need more efforts to prevent totally the status of machine breakdowns or accidents. Ms. T, the owner of company I, and Mr. M, the production manager of company $\mathrm{F}$, insist that safety is the first criterion of their company for the production processes. Both companies have developed the thorough preventive maintenances to prevent even the minor accidents.

\section{DISCUSSION}

The research results show that large companies have better performances in Lean implementation than small and medium ones. This can be explained that large companies apply the Lean philosophy officially in form of Lean projects with high commitments of top managers while small and medium firms implement Lean production in try-and-error methods without the consultancy of Lean experts. In-depth interviews of these managers indicate that, in addition to the above reasons, the large enterprises possess more advanced technology and greater specialization. With strong financial resources, it is easy for them to implement necessary tools or conduct radical changes in Lean process. Moreover, in order to confront to relentless increase of customer requirements, large enterprises have constantly innovated and cut down costs to protect their long-lasting brands, which become their daily-working culture. This culture does help to create a good foundation for them when starting to implement Lean in their enterprises. The results support the findings of previous studies such as Janet and Will (2007) which state that greater business scale and business scope each enhance long-term survival, independent of baseline profitability, owing to greater availability of financial resources, organizational routines, and external ties. The results do not support many authors who believe that Lean is more suitable for small companies than large ones such as Elbert (2013) or Harrison (1994). However, the results of this study are extracted on only six cases of large companies and four cases of small and medium ones so that they may not be generalized for the whole picture of manufacturing companies in Vietnam.

The figure 2 shows the overall picture of Lean performances of all 10 companies studied in this research. The figure states that Lean is very helpful for these companies to improve the awareness of employees and managers of customer orientation as well as reduce the labor costs. Besides, Lean also motivates the companies a lot in standardizing operations of manufacturing processes. Moreover, these companies can follow the strategies of maintenance and safety through applying Lean since it helps to prevent machine breakdowns and accidents from happening. However, the figure also reveals that the companies encounter a lot of obstacles during the time of Lean implementation. This is shown by the low performances of these companies in many factors such as flow production, Kanban, leveled production, change-over, and human automation. This can be explained that although manufacturing companies in Vietnam do not still unfamiliar with Lean; yet, they really do not know how to implement Lean effectively, especially the small and medium ones. The Vietnamese production companies really need detailed directions to conduct their Lean projects. The results support the study of Nguyen and Bui (2010) when the authors recognize the same issues of Vietnamese companies. As shown in the figure, in total, Vietnamese companies have not reached the level 4 (Minor league pro) of radar chart proposed by Hirano (2009). That means these companies have to gain much more efforts to survive into $21^{\text {st }}$ century.

\section{Trang 32}




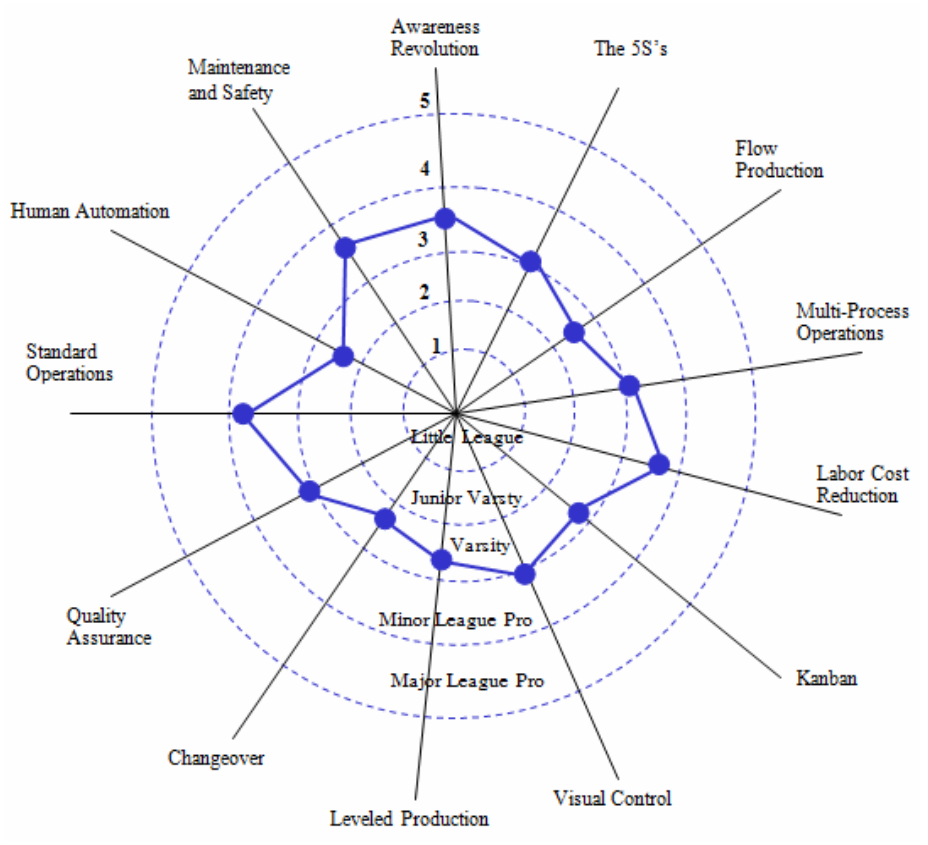

Figure 2: Overall picture of Lean performances of the manufacturing companies

In order to improve the above performances, Vietnamese manufacturing companies should focus on long-term benefits of Lean implementation. Thus, creating a Lean corporate culture is necessary for long-term strategies of businesses. In lean culture, people need to be considered as property of companies instead of labor cost; thus, companies should have training programs to improve their lean awareness and skills. Employees should be delegated to make more decisions related to their jobs and responsibility. Top managers must have strong commitments in applying Lean and supporting their staff to plan steps for Lean implementation. Top managers must not sacrifice long-term performances to attain the short-term benefit; thus, continuous improvements should be included in Lean activities to motivate the participation of all employees into the long-term organizational development. When applying Lean, there may be some resistances from employees who prefer the unchanged jobs; the Lean leaders should convince and motivate them through Lean success lessons from the other organizations or the other processes in the company. Thus, step-by-step implementation is a good strategy for Lean. Instead applying Lean quickly for the whole enterprise, the Lean leader should choose some processes in the firms that Lean can be applied successfully. Then, this success can be seen as a good example for other processes in the organization to follow. One important hint for Vietnamese companies is that they should think about an expert of Lean to get his consultancy in case the firms do not how how to start Lean philosophy or when they get stuck in somewhere during the time of Lean application.

\section{CONCLUSION}

The study recognizes that Lean performances of large companies are much better than small and medium ones based on 13 criteria of Hirano (2009). In total, the studied companies apply Lean quite well for their operations in terms of awareness revolution, the 5S's, multi-process operations, labor cost reduction, visual control, quality assurance, standard operations, maintenance and safety. These companies have low performances in flow production, Kanban, leveled production, change-over, and human automation. These companies have not yet achieved the level 4 (Minor league pro) of radar 
chart proposed by Hirano (2009). That means they have to gain much more efforts to survive into $21^{\text {st }}$ century and need more directions to have good Lean action plans, especially small and medium enterprises (SME). According to a forecast of Vietnam Ministry of Planning and Investment (2013), SMEs will attribute to $40 \%$ of total Vietnam GDP in the following year; however, these enterprises have a lot of limits in resources for their future development. For this reason, this study suggests that Vietnam government should release special supportive policies for SMEs to help them enhance their abilities in Lean adoption. This is considered as one of the most practical way for them to strengthen their competitive advantages in long term. However, the greatest limitation of this study is that just ten companies are examined and the study results may not be suitable to generalize for all Vietnamese manufacturing companies which have been applied Lean philosophy. Therefore, it is suggested that the further researches should focus on this topic with higher number of companies. The further researches can also be conducted to assess Lean performances in other sections such as service or banking.

\section{Đánh giá thành quả thực hiện lean ở các công ty Việt Nam: một nghiên cứu đa tình huống tại các doanh nghiệp sản xuất}

- Bùi Nguyên Hùng

- Lê Phước Luông

- Nguyễn Thị Hồng Đăng

Trường Đại học Bách khoa, ĐHQG-HCM

\section{TÓM TÁT:}

Nghiên cứu này được thực hiện nhằm đánh giá thành quả thực hiện Lean của 10 công ty sản xuất Việt Nam, với 13 tiêu chí được đề xuất bởi Hirano (2009). Các nhà quản lý thuộc 6 doanh nghiệp lớn và 4 doanh nghiệp vừa và nhỏ được mời để tham gia vào các buổi phỏng vấn bán cấu trúc nhằm đánh giá thành quả Lean của chính công ty họ và đưa ra ý kiến về việc đánh giá này. Kết quả nghiên cứu cho thấy các công ty lớn có kết quả đạt được tốt hơn các công ty vừa và nhỏ trên tất cả 13 yếu tố. Một cách tổng thể, các công chấp nhận được cho các tiêu chí: cải tiến về nhận thức, thực hiện 5S, vận hành đa quá trình, giảm chi phí lao động, kiểm soát trực quan, đảm bảo chất lượng, vận hành chuẩn, bảo trì và an toàn. Các công ty này phải nỗ lực nhiều hơn cho các tiêu chí: dòng sản xuất, Kanban, sản xuất theo kế hoạch, chuyển đổi, con người và tự động hóa. Để tồn tại trong bối cảnh nền kinh tế Việt Nam hiện nay, các công ty này nên tập trung vào các chiến lược lâu dài nhằm phát huy các thế mạnh của Lean cho việc phát triển của họ.

Từ khóa: Thành quả Lean, công ty sản xuất, Việt Nam. 


\section{REFERENCES}

[1]. Agus, A. \& Hajinoor, M.S. (2012). Lean production supply chain management as driver towards enhancing product quality and business performance. International Journal of Quality \& Reliability Management, Vol. 29, No. 1, pp. 92121.

[2]. Atkinson, P. (2010). Lean is a cultural issue. Management Services, Vol. 54, pp. 35-44.

[3]. Bhasin, S. (2013). Impact of corporate culture on the adoption of the Lean principles. International Journal of Lean Six Sigma, Vol. 4 No. 2, pp. 118-140.

[4]. Chong, H., White, R. \& Prybutok, V. (2001). Relationship among organizational support, JIT implementation, and performance. Industrial Management \& Data Systems, Vol. 101, No. 6, pp. 273-280.

[5]. Corbett, L. (2011). Lean Six Sigma: contribution to business excellence. International Journal of Lean Six Sigma, Vol. 2, pp. 118-131.

[6]. Eisenhardt, K. \& Martin, J. (2010). Dynamic capabilities. Strategic Management Journal, Vol. 21, p. 1105-1122.

[7]. Elbert, M. (2013). Lean production for the small company. CRC Press, Talor \& Francis Group.

[8]. FBNC Vietnam (2013). Chỉ khoảng 2\% doanh nghiệp áp dụng Lean thành công. Available on: http://www.youtube.com/watch?v=QRrwoiBNU qk, retrieved on [01-07-2013].

[9]. Harrison, B. (1994). Lean and mean: the changing landscape of corporate power in the age of flexibility. BasicBooks, ISBN: 0465069428.

[10]. Hines, P., Found, P., Griffiths, G. \& Harrison, R. (2008). Staying Lean - Thriving Not Just Surviving. LERC, London.

[11]. Hirano, H. (2009). JIT Implementation Manual, The complete guide to Just-in-Time manufacturing, Second edition. CRC Press, Talor $\&$ Francis Group.

[12]. Janet, B. \& Will, M. (2007). When is more better? The impact of business scale and scope on long-term business survival, while controlling for profitability. Strategic Management Journal, Vol. 28, Issue 1, p.61-79.

[13]. Kaplan, R. \& Norton, D.P. (2005). The office of strategic management. Strategic Finance, Vol. 87, pp. 56-60.

[14]. Karim, A. \& Zaman, K. (2013). A methodology for effective implementation of lean strategies and its performance evaluation in manufacturing organizations. Business Process Management Journal, Vol.19, No. 1, pp. 169-196.

[15]. Lean Enterprise Institute (2008). Survey of Lean Community. Available at: www.lean.org

[16]. Maltz, A., Shenhar, A. \& Reilly, R. (2003). Beyond the balanced scorecard: refining the search for organizational success measures. Long Range Planning, Vol. 36, pp. 187-204.

[17]. Naslund, D. (2008). Lean, Six sigma and lean sigma: fads or real process improvement methods? Business Process Management Journal, Vol. 14, No. 3, pp. 269-87.

[18]. Nguyen, T., D., N. \& Bui, N., H. (2010). Lean implementation in Vietnam through some cases. Journal of Development \& Integration, Vol.8, p.41-48.

[19]. Ransom, C. (2007). A Wall Street view of Lean transformation. Lean Enterprise Institute, available at: www.lean.org/events/

[20]. Ransom, C. (2008). Wall Street View of Lean Transformation. Lean Enterprise Institute, available at: www.Lean.org/events.

[21]. Shook, J. (2010). How to change a culture: lessons from Nummi. MIT Sloan Management Review, Vol. 51, pp. 63-72.

[22]. Singh, B., Garg, S. \& Sharma, S. (2010). Development of index for measuring Leanness. Measuring Business Excellence, Vol. 14, pp. 4659.

[23]. Smart, P.K., Tranfield, D., Deasley, P., Levene, R., Rowe, A. \& Corley, J. (2003). Integrating 'Lean' and 'high reliability' thinking'. Proceedings of the Institution of Mechanical Engineers, Vol. 217, No. 5, pp. 733-9. 
[24]. Socialist republic of Vietnam Government Portal (2009). Retrieved from http://vanban.chinhphu.vn/portal/

[25]. Standard, C. and Davis, D. (2000). Lean thinking for competitive advantage. Automotive Manufacturing \& Production, Vol. 112, pp. 68-9.

[26]. Vietnam Ministry of Planning and Investment (2013). Plan for the development of Small and medium enterprises to 2015. Retrieved from: http://www.ipc.soctrang.gov.vn/ [02-072013]

[27]. Vinodh, S. \& Balaji, S. (2011). Fuzzy logic based leanness assessment and its decision support system. International Journal of Production Research, Vol. 49, pp. 40-67.

[28]. Wan, H. \& Chen, F. (2008). A Leanness measure of manufacturing systems for quantifying impacts of Lean initiatives. International Journal of Production Research, Vol. 46, pp. 62-67.

[29]. Wan, H., Chen, F. \& Rivera, L. (2007). Leanness score of value stream maps. Proceedings of the 2007 Industrial Engineering Research Conference.

[30]. Womack, J. \& Jones, D. (2005). Lean Solutions. Simon \& Schuster, London.

[31]. Wooley, K. (2008). The key to a successful lean journey? Leadership! Industry Week, available at: www.industryweek.com/articles/

[32]. Wu, S. \& Wee, H (2009). How lean supply chain effects product cost and quality - a case study of the Ford Motor Company. Paper presented at IEEE Conference.

\section{Trang 36}

